\title{
Deinococcus reticulitermitis sp. nov., isolated from a termite gut
}

\author{
Correspondence \\ Hong Yang \\ hyang@mail.ccnu.edu.cn
}

\author{
Wen Chen, ${ }^{1}$ Baojun Wang, ${ }^{2}$ Huazhu Hong, ${ }^{1}$ Hong Yang ${ }^{1}$ \\ and Shuang-Jiang Liu ${ }^{2}$
}

\author{
${ }^{1}$ Key Laboratory of Pesticide \& Chemical Biology, Ministry of Education, College of Life Sciences, \\ Central China Normal University, Wuhan 430079, PR China \\ ${ }^{2}$ State Key Laboratory of Microbial Resources, Institute of Microbiology, \\ Chinese Academy of Sciences, Beijing 100101, PR China
}

\begin{abstract}
Bacterial strain $\mathrm{TM}^{\top}{ }^{\top}$ was isolated from the gut of a wood-feeding termite, Reticulitermes chinensis Snyder. Cells of strain TM-1 ${ }^{\top}$ were Gram-negative, spherical (1.0-2.0 $\mu \mathrm{m}$ in diameter), non-motile, non-sporulating and red-pigmented. Strain $\mathrm{TM}-1^{\top}$ was resistant to UV radiation, showing $34 \%$ survival after exposure to UV light at a dose of $100 \mathrm{~J} \mathrm{~m}^{-2}$. Growth occurred at $20-40{ }^{\circ} \mathrm{C}$ (optimum, $30{ }^{\circ} \mathrm{C}$ ), at $\mathrm{pH} 6.0-10.0$ (optimum, $\mathrm{pH} 6.0-7.0$ ), and in the presence of 0-1\% (w/v) $\mathrm{NaCl}$ (optimum, 0-0.4\%). Phylogenetic analysis based on 16S rRNA gene sequences indicated that strain $\mathrm{TM}-1^{\top}$ was related to members of the genus Deinococcus, with sequence similarities ranging from 87.0 to $94.0 \%$. The peptidoglycan of strain $\mathrm{TM}-1^{\top}$ contained ornithine, alanine, glycine and glutamic acid. The most abundant cellular fatty acids of strain $\mathrm{TM}-1^{\top}$ were summed feature 3 $\left(\mathrm{C}_{16: 1} \omega 7 c\right.$ and/or $\left.\mathrm{C}_{16: 1} \omega 6 c ; 22.3 \%\right)$ and $\mathrm{C}_{16: 0}(37.5 \%)$. MK-8 was the predominant quinone. The polar lipid profile contained three glycophospholipids, six glycolipids, one aminolipid and three unknown lipids. DNA of the type strain had a $\mathrm{G}+\mathrm{C}$ content of $65.6 \mathrm{~mol} \%$. Based on the phylogenetic, chemotaxonomic and phenotypic data presented, strain $\mathrm{TM}-1^{\top}$ represents a novel species of the genus Deinococcus, for which the name Deinococcus reticulitermitis sp. nov. is proposed, with $\mathrm{TM}-1^{\top}\left(=\mathrm{CGMCC} 1.10218^{\top}=\mathrm{NBRC} 106334^{\top}\right)$ as the type strain.
\end{abstract}

The genus Deinococcus (Brooks \& Murray, 1981) represents a deep-branching lineage within the 'Bacteria'. At the time of writing, the genus comprised 46 species with validly published names isolated from various environments such as desert soil (Rainey et al., 2005), air (Weon et al., 2007; Yoo et al., 2010), water (Kämpfer et al., 2008), a hot spring (Ferreira et al., 1997), continental Antarctica (Hirsch et al., 2004) and fish (Shashidhar \& Bandekar, 2009). Most species of this genus are resistant to UV and gamma radiation. However, four psychrophilic, ionizing-radiationsensitive Deinococcus species, isolated from alpine environments, have been described recently (Callegan et al., 2008). A UV-radiation-resistant strain, Deinococcus xinjiangensis $\mathrm{X}-82^{\mathrm{T}}$, which was isolated from a desert soil sample of Xinjiang region, China, was found to be sensitive to gamma radiation and desiccation (Peng et al., 2009).

During the course of a study on the diversity of culturable bacteria in the gut of a wood-feeding termite, Reticulitermes chinensis Snyder (Isoptera: Rhinotermitidae), bacterial strain

The GenBank/EMBL/DDBJ accession number for the 16S rRNA gene sequence of strain $\mathrm{TM}-1^{\top}$ is $\mathrm{HM} 214546$.

Five supplementary figures and one supplementary table are available with the online version of this paper.
TM $-1^{\mathrm{T}}$ was isolated by the serial dilution method. Termites were collected from Guizi Mountain in Wuhan, China and fed with pine wood in the laboratory for 1 year. To obtain enrichment cultures, 10 worker termites were surfacesterilized in $70 \%$ ethanol and then washed in sterile distilled water. The entire guts were removed from the abdomen and disrupted with sterile fine-tipped forceps. The hindgut contents were suspended in $1 \mathrm{ml}$ sterile phosphate buffer (PBS: $0.137 \mathrm{M} \mathrm{NaCl}, 10 \mathrm{mM} \mathrm{Na} \mathrm{HPO}_{4}, 2.7 \mathrm{mM} \mathrm{KCl}$ and $2 \mathrm{mM} \mathrm{KH} \mathrm{PO}_{4}, \mathrm{pH} 7.4$ ) and serially diluted. The dilution was then spread on agar plates with basal medium MM-4 modified from Brune et al. (1995) that contained ( $\mathrm{g} \mathrm{l}^{-1}$, unless otherwise stated): $\mathrm{NaCl}, 1 ; \mathrm{KCl}, 0.5 ; \mathrm{MgCl} .6 \mathrm{H}_{2} \mathrm{O}, 0.1$; $\mathrm{CaCl}$. 2 $\mathrm{H}_{2} \mathrm{O}, 0.015 ; \mathrm{NH}_{4} \mathrm{Cl}, 0.3 ; \mathrm{KH}_{2} \mathrm{PO}_{4}, 0.2 ; \mathrm{Na}_{2} \mathrm{SO}_{4}, 0.15$; Bacto yeast extract, 0.5; Casamino acids, 0.5; PBS, $20 \mathrm{mM}$; trace element solution SL 11 (Eichler \& Pfennig, 1986), $1 \mathrm{ml}$; and seven-vitamin solution (Janssen et al., 1997), $1 \mathrm{ml}$. The plates were incubated at $30{ }^{\circ} \mathrm{C}$ for 1 week. Colonies exhibiting different morphologies on the plates were picked up and subcultured to obtain pure cultures. Strain TM-1 ${ }^{\mathrm{T}}$ was isolated from a single red-pigmented colony.

The nearly complete $16 \mathrm{~S}$ rRNA gene of strain TM-1 ${ }^{\mathrm{T}}$ (1469 bp) was amplified and sequenced as described previously (Ying et al., 2007). DNA BLAST searches (Altschul et al., 
1990) of 16S rRNA gene sequences using the NCBI database showed that strain $\mathrm{TM}-1^{\mathrm{T}}$ was phylogenetically related to members of the genus Deinococcus. The partial 16S rRNA gene sequence was aligned with those of species of the genus Deinococcus by using the program CLUSTAL_X version $1.64 \mathrm{~b}$ (Thompson et al., 1997). A maximum-likelihood phylogenetic tree (Fig. 1) was constructed using fastDNAml (Olsen et al., 1994; Felsenstein, 1981) included in PHYLIP v3.5 (Felsenstein, 1993). A neighbour-joining phylogenetic tree (Supplementary Fig. S1, available in IJSEM Online) and a maximum-parsimony phylogenetic tree (Supplementary Fig. S2, available in IJSEM Online) were constructed using MEGA version 4.1 (Kumar et al., 2004). Topology of the phylogenetic trees was evaluated by the bootstrap resampling method based on 1000 replicates.

Analysis of 16S rRNA gene sequences indicated that strain $\mathrm{TM}-1^{\mathrm{T}}$ was phylogenetically related to members of the genus Deinococcus with sequence similarities ranging from 87.0 to $94.0 \%$. In particular, strain $\mathrm{TM}-1^{\mathrm{T}}$ was closely related to Deinococcus gobiensis $\mathrm{I}-0^{\mathrm{T}}(94.0 \%)$ (Yuan et al., 2009), Deinococcus aquaticus $\mathrm{PB} 314^{\mathrm{T}}(94.0 \%)$ (Im et al., 2008) and Deinococcus caeni Ho- $08^{\mathrm{T}}$ (94.0\%) (Im et al., 2008); 16S rRNA gene sequence similarities with strains

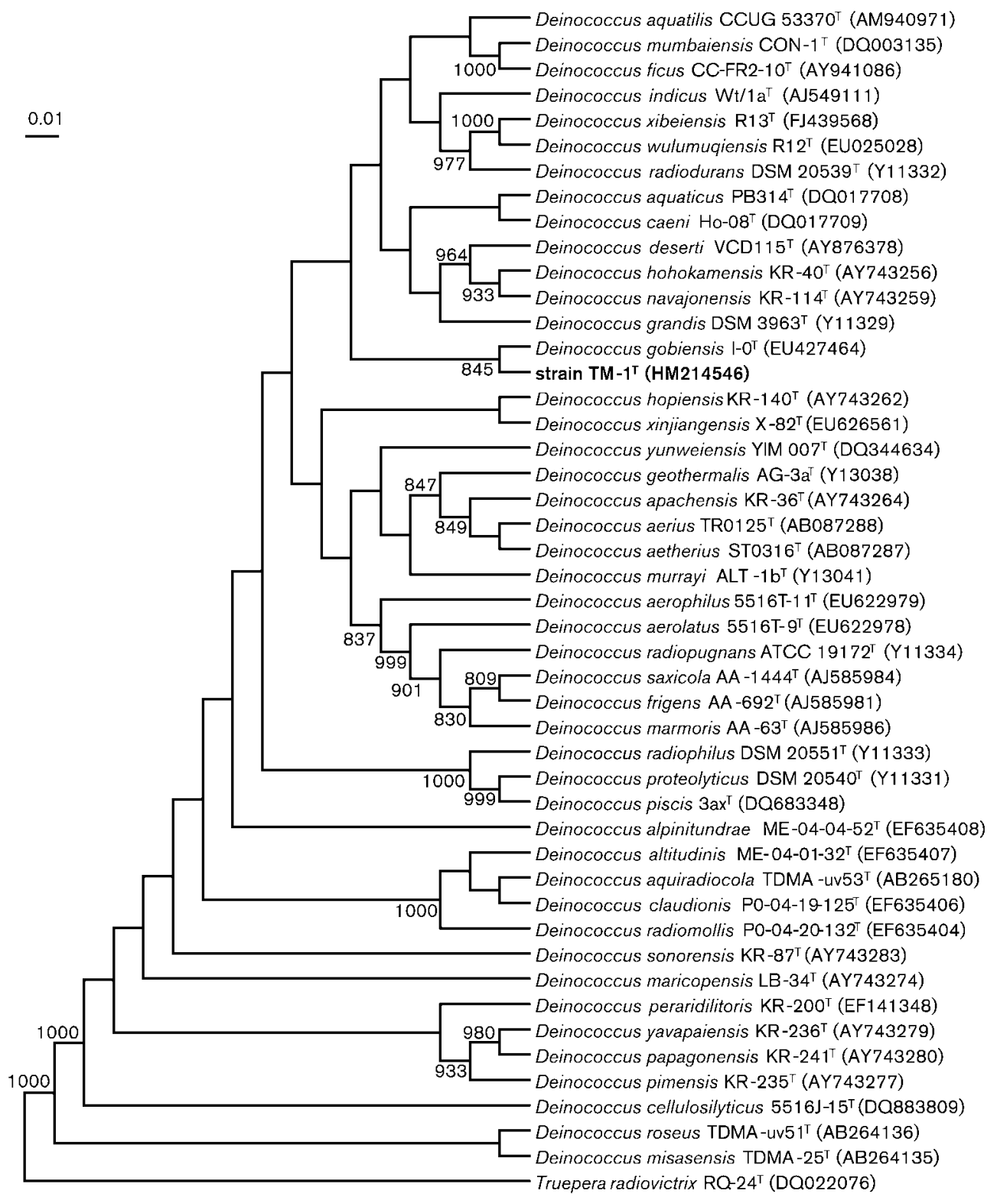

Fig. 1. Phylogenetic tree constructed with the maximum-likelihood method based on the $16 \mathrm{~S}$ rRNA gene sequences of TM-1 ${ }^{\top}$ and other Deinococcus species. Truepera radiovictrix RQ $-24^{\top}$ was used as an outgroup. GenBank accession numbers are given in parentheses. Bootstrap values (1000 replicates) higher than 700 out of 1000 were shown. Bar, 0.01 substitutions per nucleotide position. 
of all other Deinococcus species were lower. Phylogenetic analysis (Fig. 1) showed that strain $\mathrm{TM}-1^{\mathrm{T}}$ formed a unique cluster with Deinococcus gobiensis $\mathrm{I}-0^{\mathrm{T}}$ in phylogenetic trees constructed with the maximum-likelihood (Fig. 1), neighbour-joining (Supplementary Fig. S1, available in IJSEM Online) and maximum-parsimony (Supplementary Fig. S2, available in IJSEM Online) methods.

Cultural and morphological characteristics were observed on MM-4 agar plates. Growth was also assessed in threefolddiluted tryptic soy broth (TSB/3; $10 \mathrm{~g} \mathrm{l}^{-1}$; Bacto; Becton Dickinson), but no growth was detected on undiluted TSB or Luria-Bertani (LB) broth. Gram-staining was performed as described by Gerhardt et al. (1994). Morphological observations were performed by scanning electron microscopy (FEI Quanta 200). The presence of flagella and cell mobility were examined according to Dong \& Cai (2001). The basic physiological and biochemical characteristics of strain TM$1^{\mathrm{T}}$ were investigated using routine cultivation in MM-4 broth at $30{ }^{\circ} \mathrm{C}$. The temperature range $\left(9,20,30,40,50{ }^{\circ} \mathrm{C}\right)$ was determined with a TN3F temperature-gradient incubator (Advantec). Growth at different $\mathrm{pH}$ (4.5-10.5 at intervals of $0.5 \mathrm{pH}$ units) was tested by using $\mathrm{MM}-4$ in which the $\mathrm{pH}$ was adjusted by the addition of $5 \mathrm{M} \mathrm{NaOH}$ or $\mathrm{HCl}$ and verified after autoclaving. Tolerance to $\mathrm{NaCl}$ was tested in MM-4 medium with $0,0.1,0.2,0.4,1.0,2.0$ and $4.0 \%(\mathrm{w} / \mathrm{v}) \mathrm{NaCl}$. Metabolic properties were determined using API 20NE test kits (bioMérieux) according to the manufacturer's instructions at $30{ }^{\circ} \mathrm{C}$. Tests for catalase and oxidase activities and hydrolysis of starch were carried out according to Dong \& Cai (2001).

Cell-wall peptidoglycan analysis was performed with a method modified from Staneck \& Roberts (1974) and Dong \& Cai (2001) with D. gobiensis $\mathrm{I}-0^{\mathrm{T}}$ as a reference. Approximately $30 \mathrm{mg}$ (wet wt) of cells was placed into a small ampoule with $1 \mathrm{ml}$ absolute alcohol overnight. The alcohol was then discarded and cells were air-dried. Cell pellets were resuspended in $0.1 \mathrm{ml} 6 \mathrm{M} \mathrm{HCl}$. The sealed ampoule was kept at $120{ }^{\circ} \mathrm{C}$ for $20 \mathrm{~min}$. Before chromatography, the TLC sheet (crystallite cellulose plate; Anhui LiangChen Silicon Material) was activated at $110{ }^{\circ} \mathrm{C}$ for $30 \mathrm{~min}$. Samples of cell wall preparation and standard amino acids were applied at the base line of the TLC sheet. Ascending TLC was performed with the solvent system methanol/pyridine/acetic acid/distilled water $(5.0: 0.5: 0.125$ : 2.5 , by vol.) for approximately $3.5 \mathrm{~h}$. After the chromatogram was air-dried, spots were visualized by spraying with $0.4 \%$ ninhydrin in butyl alcohol and heating at $70{ }^{\circ} \mathrm{C}$ for $5 \mathrm{~min}$.

Fatty acids were extracted, methylated and analysed in parallel with those of $D$. gobiensis $\mathrm{I}-0^{\mathrm{T}}$ and Deinococcus radiodurans CGMCC $1.633^{\mathrm{T}}$ according to the standard protocol of the Sherlock Microbial Identification System (MIDI; Microbial ID; http://www.microbialid.com/PDF/ TechNote_101.pdf) except that cells were grown on TSB/3 agar plates. Menaquinones were extracted and purified according to the method of Collins (1985) and were analysed by HPLC (Wu et al., 1989) with $D$. radiodurans CGMCC $1.633^{\mathrm{T}}$ as a reference. Polar lipids were extracted according to the method of Zhang et al. (2010) and separated by TLC on Merck Kieselgel 60-HPTLC by twodimensional development as described by Ross et al. (1985). Phospholipids were detected with the Zinzadze reagent of Dittmer \& Lester (1964). Glycolipids were detected by spraying the plate with $0.5 \%$ l-naphthol in methanol/water $(1: 1, \mathrm{v} / \mathrm{v})$ and then with sulfuric acid/ ethanol $(1: 1, \mathrm{v} / \mathrm{v})$, followed by heating at $120{ }^{\circ} \mathrm{C}$ for $5-$ $10 \mathrm{~min}$ (Xin et al., 2001). Aminolipids were detected by spraying with ninhydrin reagent $(0.2 \mathrm{~g}$ ninhydrin in $100 \mathrm{ml}$ ethanol) and heating at $120{ }^{\circ} \mathrm{C}$. Whole lipids were detected by spraying with molybdatophosphoric acid (10 g molybdatophosphoric acid hydrate in $100 \mathrm{ml}$ ethanol) followed by heating at $120-160{ }^{\circ} \mathrm{C}$ (Worliczek et al., 2007). The DNA $\mathrm{G}+\mathrm{C}$ content was determined by thermal denaturation (Marmur \& Doty, 1962), with Escherichia coli $\mathrm{K}-12$ as a reference.

To determine the tolerance of the isolate to UV radiation, strain $\mathrm{TM}-1^{\mathrm{T}}$ was grown in TSB/3 liquid medium to the exponential phase; D. radiodurans CGMCC $1.633^{\mathrm{T}}$ and $E$. coli K-12 were tested as positive and negative controls. Cells were recovered by centrifugation, washed with sterile PBS and serially diluted. Aliquots of $0.1 \mathrm{ml}$ from each dilution were spread in triplicate on TSB/3 agar plates (with their lids open), exposed to UV light (254 nm) for dosages of 100 , 200, 400, 600, 800 and $1000 \mathrm{~J} \mathrm{~m}^{-2}$, and then incubated in the dark at $30{ }^{\circ} \mathrm{C}$ for 10 days. Relative survival was determined by comparing colony counts of irradiated cells with unirradiated cultures.

Strain $\mathrm{TM}-1^{\mathrm{T}}$ stained Gram-negative and formed visible (about $1 \mathrm{~mm}$ ) red-pigmented colonies within $72 \mathrm{~h}$ at $30{ }^{\circ} \mathrm{C}$ on MM-4 agar. The colonies were translucent and shiny with entire edges after 3 days of cultivation. Strain TM- $1^{\mathrm{T}}$ was an oxidase-negative, catalase-positive, non-motile and nonspore-forming coccus $(1.0-2.0 \mu \mathrm{m}$ in diameter) (Supplementary Fig. S3, available in IJSEM Online). It was not able to use carboxymethylcellulose for growth. Additional physiological and biochemical properties of strain $\mathrm{TM}-1^{\mathrm{T}}$ are provided in the species description and the properties that distinguish strain $\mathrm{TM}-1^{\mathrm{T}}$ from its closely related species are listed in Table 1.

The peptidoglycan of strain $\mathrm{TM}-1^{\mathrm{T}}$ contained ornithine, alanine, glycine and glutamic acid, which was also observed in its phylogenetically closest relative, $D$. gobiensis $\mathrm{I}-0^{\mathrm{T}}$. The most abundant cellular fatty acids of strain $\mathrm{TM}-1^{\mathrm{T}}$ were summed feature $3\left(\mathrm{C}_{16: 1} \omega 7 c\right.$ and/or $\left.\mathrm{C}_{16: 1} \omega 6 c ; 22.3 \%\right)$ and $\mathrm{C}_{16: 0}(37.5 \%)$, which are also predominant in most other Deinococcus species (Supplementary Table S1, available in IJSEM Online). However, some qualitative and quantitative differences in fatty acid composition could be observed between strain $\mathrm{TM}-1^{\mathrm{T}}$ and its phylogenetically closest relatives. For example, the proportion of summed feature 3 in strain $\mathrm{TM}-1^{\mathrm{T}}$ was similar to that observed in $D$. radiodurans CGMCC $1.633^{\mathrm{T}}$, D. gobiensis $\mathrm{I}-0^{\mathrm{T}}$ and Deinococcus 
Table 1. Differential phenotypic characteristics of strain $\mathrm{TM}-1^{\top}$ and related members of the genus Deinococcus

Strains: 1, TM-1 ${ }^{\mathrm{T}}$; 2, D. gobiensis $\mathrm{I}-0^{\mathrm{T}}$; 3, D. radiodurans CGMCC $1.633^{\mathrm{T}}$; 4, D. aquaticus $\mathrm{PB} 314^{\mathrm{T}}$ (Im et al., 2008); 5, D. caeni Ho-08 ${ }^{\mathrm{T}}$ (Im et al., 2008); 6, D. aquiradiocola TDMA-uv53 $3^{\mathrm{T}}$ (Asker et al., 2009). For phenotypic characterization, strain TM- $1^{\mathrm{T}}$, D. gobiensis $\mathrm{I}-0^{\mathrm{T}}$ and $D$. radiodurans CGMCC $1.633^{\mathrm{T}}$ were tested in parallel in this study with API 20NE. +, Positive; -, negative; $(+)$, weakly positive; ND, not determined.

\begin{tabular}{|c|c|c|c|c|c|c|}
\hline Characteristic & 1 & 2 & 3 & 4 & 5 & 6 \\
\hline Colony colour ${ }^{\star}$ & $\mathrm{R}$ & PR & $\mathrm{R}$ & $\mathrm{R}$ & $\mathrm{P}$ & PP \\
\hline $\mathrm{pH}$ growth range & $6.0-10.0$ & $7.0-8.0$ & $\mathrm{ND}$ & $6.0-9.5$ & $6.5-9.5$ & $5.0-9.0$ \\
\hline Oxidase activity & - & + & + & + & - & + \\
\hline Starch hydrolysis & $(+)$ & + & ND & + & + & + \\
\hline Arginine dihydrolase activity & - & - & - & - & - & ND \\
\hline Urease activity & - & + & - & - & - & - \\
\hline Aesculin hydrolysis & + & + & - & + & - & + \\
\hline Gelatin hydrolysis & + & + & - & - & - & + \\
\hline$\beta$-Galactosidase activity & + & + & - & + & ND & + \\
\hline D-Mannose & + & + & + & + & - & + \\
\hline D-Mannitol & - & + & - & - & - & + \\
\hline $\mathrm{N}$-Acetylglucosamine & - & - & - & + & + & - \\
\hline Maltose & + & + & - & + & + & + \\
\hline Gluconate & - & - & - & + & + & - \\
\hline Capric acid & - & - & - & - & - & - \\
\hline Adipic acid & - & - & - & - & - & - \\
\hline Malic acid & $(+)$ & - & + & + & - & - \\
\hline Citrate & - & - & - & - & - & - \\
\hline Phenylacetic acid & - & - & - & - & - & - \\
\hline DNA G $+C$ content $(\mathrm{mol} \%)$ & 65.6 & 65.4 & 67 & 68.3 & 68.4 & 69.1 \\
\hline
\end{tabular}

${ }^{\star} \mathrm{R}$, Red; PR, pink-red; P, pink; PP, pale pink.

aquiradiocola TDMA-uv53 ${ }^{\mathrm{T}}$ but lower than that found in D. aquaticus $\mathrm{PB} 314^{\mathrm{T}}$ and D. caeni $\mathrm{Ho}-08^{\mathrm{T}}$. In addition, in contrast to the other five Deinococcus strains listed in Supplementary Table S1 (available in IJSEM Online), strain TM-1 ${ }^{\mathrm{T}}$ produced higher proportions of $\mathrm{C}_{14: 0}$, iso- $\mathrm{C}_{13: 0}$ $3-\mathrm{OH}$, iso- $\mathrm{C}_{15: 1} \mathrm{~F}$, anteiso- $\mathrm{C}_{15: 1} \mathrm{~A}$ and anteiso- $\mathrm{C}_{17: 1} \omega 9 c$.

A complex polar lipid profile of strain $\mathrm{TM}-1^{\mathrm{T}}$ was shown by two-dimensional TLC analysis (Supplementary Fig. S4, available in IJSEM Online). The predominant polar lipids were phosphoglycolipid $\left(\mathrm{PGL}_{2}\right)$, which was consistent with previous results for Deinococcus species (Anderson \& Hansen, 1985; Ferreira et al., 1997; Im et al., 2008; Peng et al., 2009). Moreover, strain TM-1 ${ }^{\mathrm{T}}$ showed unknown phosphoglycolipids $\mathrm{PGL}_{1}$ and $\mathrm{PGL}_{4}$, glycolipids $\mathrm{GL}_{2}, \mathrm{GL}_{3}, \mathrm{GL}_{4}, \mathrm{GL}_{5}, \mathrm{GL}_{6}$ and $\mathrm{GL}_{7}$, aminolipid $\mathrm{AL}$, and three unknown polar lipids $\mathrm{L}_{1}$, $\mathrm{L}_{2}$ and $\mathrm{L}_{3}$, which were also detected in other Deinococcus species (Im et al., 2008; Kämpfer et al., 2008). However, the unique combination of unknown polar lipids distinguished it from other Deinococcus species. The predominant isoprenoid quinone of TM-1 $1^{\mathrm{T}}$ was MK-8, which was typical of members of the genus Deinococcus. The DNA G+C content was $65.6 \mathrm{~mol} \%$, a value that was within the range found for other species of the genus Deinococcus (Hirsch et al., 2004).

Strain TM- $1^{\mathrm{T}}$ could tolerate UV irradiation, showing $34 \%$ survival after exposure to UV light at a dose of $100 \mathrm{~J} \mathrm{~m}^{-2}$. Strain $\mathrm{TM}-1^{\mathrm{T}}$ and D. radiodurans CGMCC $1.633^{\mathrm{T}}$ could grow at a higher dose $\left(600 \mathrm{~J} \mathrm{~m}^{-2}\right)$, whereas E. coli $\mathrm{K}-12$ showed no resistance at this dose (Supplementary Fig. S5, available in IJSEM Online).

Based on the above phenotypic and phylogenetic studies, it is clear that strain $\mathrm{TM}-1^{\mathrm{T}}$ is a member of the genus Deinococcus. However, strain $\mathrm{TM}-1^{\mathrm{T}}$ could be distinguished from its closest relative $D$. gobiensis $\mathrm{I}-0^{\mathrm{T}}$ by differences in oxidase and urease activities. In addition, the assimilation of various carbon sources such as glucose, mannitol and malic acid differed in the two strains (Table 1). Considering other chemotaxonomic and phenotypic characteristics, and 16S rRNA gene sequence analysis, it is concluded that bacterial 
strain $\mathrm{TM}-1^{\mathrm{T}}$ represents a novel species of the genus Deinococcus; the name Deinococcus reticulitermitis sp. nov. is proposed.

\section{Description of Deinococcus reticulitermitis sp. nov.}

Deinococcus reticulitermitis (re.ti.cu.li.ter'mi.tis. N.L. n. reticulitermitis a termite of the genus Reticulitermes).

Cells are spherical, non-motile and stain Gram-negative. Colonies on MM-4 agar are red-pigmented, smooth, convex, circular, uniform-edged and $1-2 \mathrm{~mm}$ in diameter. No growth is detected on TSB or LB broth. Grows on MM-4 and TSB $/ 3$ at $30{ }^{\circ} \mathrm{C}$. Growth occurs at $20-40{ }^{\circ} \mathrm{C}$ (optimum, $30{ }^{\circ} \mathrm{C}$ ), at $\mathrm{pH} 6.0-10.0$ (optimum, $\mathrm{pH} 6.0-7.0$ ), and in the presence of $0-1.0 \%(\mathrm{w} / \mathrm{v}) \mathrm{NaCl}$ (optimum, $0-0.4 \%$ ). Nitrate is reduced. Aesculin, gelatin and starch are hydrolysed. $\beta$-Galactosidase is positive. Urease, oxidase and arginine dihydrolase activities are absent. Indole is not produced. Assimilates D-mannose, maltose and malic acid, but not Dglucose, L-arabinose, D-mannitol, $\mathrm{N}$-acetyl-D-glucosamine, gluconate, caprate, phenylacetate, adipate, malate or citrate. The major cellular fatty acids are summed feature 3 $\left(\mathrm{C}_{16: 1} \omega 7 c\right.$ and/or $\left.\mathrm{C}_{16: 1} \omega 6 c\right), \mathrm{C}_{16: 0}, \mathrm{C}_{14: 0}$ and $\mathrm{C}_{18: 0}$. The peptidoglycan contains ornithine, alanine, glycine and glutamic acid. MK-8 is the predominant lipoquinone. The polar lipid profile contains three glycophospholipids, six glycolipids, one aminolipid and three unknown lipids.

The type strain is $\mathrm{TM}-1^{\mathrm{T}}\left(=\mathrm{CGMCC} 1.10218^{\mathrm{T}}=\mathrm{NBRC}\right.$ $106334^{\mathrm{T}}$ ), isolated from the gut of a wood-feeding termite, Reticulitermes chinensis Snyder, from China. The DNA $\mathrm{G}+\mathrm{C}$ content of the type strain is $65.6 \mathrm{~mol} \%$.

\section{Acknowledgements}

This work was supported by grants from the National Natural Science Foundation of China (30570034, 30970001).

\section{References}

Altschul, S. F., Gish, W., Miller, W., Myers, E. W. \& Lipman, D. J. (1990). Basic local alignment search tool. J Mol Biol 215, 403-410.

Anderson, R. \& Hansen, K. (1985). Structure of a novel phosphoglycolipid from Deinococcus radiodurans. J Biol Chem 260, 1221912223.

Asker, D., Awad, T. S., Beppu, T. \& Ueda, K. (2009). Deinococcus aquiradiocola sp. nov., isolated from a radioactive site in Japan. Int $J$ Syst Evol Microbiol 59, 144-149.

Brooks, B. W. \& Murray, R. G. E. (1981). Nomenclature for "Micrococcus radiodurans" and other radiation-resistant cocci: Deinococcaceae fam. nov. and Deinococcus gen. nov., including five species. Int J Syst Bacteriol 31, 353-360.

Brune, A., Miambi, E. \& Breznak, J. A. (1995). Roles of oxygen and the intestinal microflora in the metabolism of lignin-derived phenylpropanoids and other monoaromatic compounds by termites. Appl Environ Microbiol 61, 2688-2695.

Callegan, R. P., Nobre, M. F., McTernan, P. M., Battista, J. R., NavarroGonzález, R., McKay, C. P., da Costa, M. S. \& Rainey, F. A. (2008).
Description of four novel psychrophilic, ionizing radiation-sensitive Deinococcus species from alpine environments. Int J Syst Evol Microbiol 58, 1252-1258.

Collins, M. D. (1985). Isoprenoid quinone analysis in classification and identification. In Chemical Methods in Bacterial Systematics, pp. 267-287. Edited by M. Goodfellow \& D. E. Minnikin. London: Academic Press.

Dittmer, J. C. \& Lester, R. L. (1964). A simple, specific spray for the detection of phospholipids on thin-layer chromatograms. J Lipid Res 15, 126-127.

Dong, X.-Z. \& Cai, M.-Y. (editors) (2001). Determination of biochemical properties. In Manual for the Systematic Identification of General Bacteria, pp. 370-398. Beijing: Scientific Press (English translation).

Eichler, B. \& Pfennig, N. (1986). Characterization of a new plateletforming purple sulfur bacterium, Amoebobacter pedioformis sp. nov. Arch Microbiol 146, 295-300.

Felsenstein, J. (1981). Evolutionary trees from DNA sequences: a maximum likelihood approach. J Mol Evol 17, 368-376.

Felsenstein, J. (1993). PHYLIP (phylogeny inference package) version 3.5.1. Distributed by the author. Department of Genome Sciences, University of Washington, Seattle, USA.

Ferreira, A. C., Nobre, M. F., Rainey, F. A., Silva, M. T., Wait, R., Burghardt, J., Chung, A. P. \& da Costa, M. S. (1997). Deinococcus geothermalis sp. nov. and Deinococcus murrayi sp. nov., two extremely radiation-resistant and slightly thermophilic species from hot springs. Int J Syst Bacteriol 47, 939-947.

Gerhardt, P., Murray, R. G. E., Wood, W. A. \& Krieg, N. R. (1994). Methods for General and Molecular Bacteriology. Washington, DC: American Society for Microbiology.

Hirsch, P., Gallikowski, C. A., Siebert, J., Peissl, K., Kroppenstedt, R., Schumann, P., Stackebrandt, E. \& Anderson, R. (2004). Deinococcus frigens sp. nov., Deinococcus saxicola sp. nov., and Deinococcus marmoris sp. nov., low temperature and draught-tolerating, UVresistant bacteria from continental Antarctica. Syst Appl Microbiol 27, 636-645.

Im, W.-T., Jung, H.-M., Ten, L. N., Kim, M. K., Bora, N., Goodfellow, M., Lim, S., Jung, J. \& Lee, S. T. (2008). Deinococcus aquaticus sp. nov., isolated from fresh water, and Deinococcus caeni sp. nov., isolated from activated sludge. Int J Syst Evol Microbiol 58, 2348-2353.

Janssen, P. H., Schuhmann, A., Mörschel, E. \& Rainey, F. A. (1997). Novel anaerobic ultramicrobacteria belonging to the Verrucomicrobiales lineage of bacterial descent isolated by dilution culture from anoxic rice paddy soil. Appl Environ Microbiol 63, 1382-1388.

Kämpfer, P., Lodders, N., Huber, B., Falsen, E. \& Busse, H. J. (2008). Deinococcus aquatilis sp. nov., isolated from water. Int J Syst Evol Microbiol 58, 2803-2806.

Kumar, S., Tamura, K. \& Nei, M. (2004). MEGA3: integrated software for Molecular Evolutionary Genetics Analysis and sequence alignment. Brief Bioinform 5, 150-163.

Marmur, J. \& Doty, P. (1962). Determination of the base composition of deoxyribonucleic acid from its thermal denaturation temperature. J Mol Biol 5, 109-118.

Olsen, G. J., Matsuda, H., Hagstrom, R. \& Overbeek, R. (1994). fastDNAmL: a tool for construction of phylogenetic trees of DNA sequences using maximum likelihood. Comput Appl Biosci 10, 41-48.

Peng, F., Zhang, L., Luo, X.-S., Dai, J., An, H.-L., Tang, Y.-L. \& Fang, C.-X. (2009). Deinococcus xinjiangensis sp. nov., isolated from desert soil. Int J Syst Evol Microbiol 59, 709-713.

Rainey, F. A., Ray, K., Ferreira, M., Gatz, B. Z., Nobre, M. F., Bagaley, D., Rash, B. A., Park, M.-J., Earl, A. M. \& other authors (2005). Extensive 
diversity of ionizing-radiation-resistant bacteria recovered from Sonoran Desert soil and description of nine new species of the genus Deinococcus obtained from a single soil sample. Appl Environ Microbiol 71, 5225-5235.

Ross, H. N. M., Grant, W. D. \& Harris, J. E. (1985). Lipids in archaebacterial taxonomy. In Chemical Methods in Bacterial Systematics, pp. 280-300. Edited by M. Goodfellow \& D. E. Minnikin. London: Academic Press.

Shashidhar, R. \& Bandekar, J. R. (2009). Deinococcus piscis sp. nov., a radiation-resistant bacterium isolated from a marine fish. Int J Syst Evol Microbiol 59, 2714-2717.

Staneck, J. L. \& Roberts, G. D. (1974). Simplified approach to identification of aerobic actinomycetes by thin-layer chromatography. Appl Microbiol 28, 226-231.

Thompson, J. D., Gibson, T. J., Plewniak, F., Jeanmougin, F. \& Higgins, D. G. (1997). The CLUSTAL_X windows interface: flexible strategies for multiple sequence alignment aided by quality analysis tools. Nucleic Acids Res 25, 4876-4882.

Weon, H. Y., Kim, B. Y., Schumann, P., Son, J. A., Jang, J., Go, S. J. \& Kwon, S. W. (2007). Deinococcus cellulosilyticus sp. nov., isolated from air. Int J Syst Evol Microbiol 57, 1685-1688.

Worliczek, H. L., Kämpfer, P., Rosengarten, R., Tindall, B. J. \& Busse, H. J. (2007). Polar lipid and fatty acid profiles - re-vitalizing old approaches as a modern tool for the classification of mycoplasmas? Syst Appl Microbiol 30, 355-370.

Wu, C., Lu, X., Qin, M., Wang, Y. \& Ruan, J. (1989). Analysis of menaquinone compound in microbial cells by HPLC. Microbiology [English translation of Microbiology (Beijing)] 16, 176-178.

Xin, H., Itoh, T., Zhou, P., Suzuki, K. \& Nakase, T. (2001). Natronobacterium nitratireducens sp. nov., a aloalkaliphilic archaeon isolated from a soda lake in China. Int J Syst Evol Microbiol 51, 18251829.

Ying, J.-Y., Liu, Z.-P., Wang, B.-J., Dai, X., Yang, S.-S. \& Liu, S.-J. (2007). Salegentibacter catena sp. nov., isolated from sediment of the South China Sea, and emended description of the genus Salegentibacter. Int J Syst Evol Microbiol 57, 219-222.

Yoo, S. H., Weon, H.-Y., Kim, S.-J., Kim, Y.-S., Kim, B.-Y. \& Kwon, S.-W. (2010). Deinococcus aerolatus sp. nov. and Deinococcus aerophilus sp. nov., isolated from air samples. Int J Syst Evol Microbiol 60, 1191-1195.

Yuan, M.-L., Zhang, W., Dai, S., Wu, J., Wang, Y.-D., Tao, T.-S., Chen, M. \& Lin, M. (2009). Deinococcus gobiensis sp. nov., an extremely radiationresistant bacterium. Int J Syst Evol Microbiol 59, 1513-1517.

Zhang, J.-Y., Liu, X.-Y. \& Liu, S.-J. (2010). Sphingomonas changbaiensis sp. nov., isolated from forest soil. Int J Syst Evol Microbiol 60, 790795. 